\title{
Sanat ve Pazarlamanın "Sıra Dışı" Birlikteliği*
}

\author{
Yrd. Doç. Dr. Feyza AĞLARGöz \\ Prof. Dr. Sevgi Ayşe ÖZTÜRK
}

anadolu üniversitesi iibf işletme bölümü feyzak@anadolu.edu.tr sozturk@anadolu.edu.tr

\section{Abstract}

\section{The "Weird" Marriage of Art and Marketing}

This study examines the art and marketing in the context of the historical-traditional discussions about the field and it aims to find out a more concrete definition of "arts marketing" by specifying its differences from traditional marketing. Presenting the relation between art and commerce -past's contradictious, today's attractive, provocative and ordinary relation- we concluded that the arts marketing which was seen as a series of technical and decision-making in the past, are now being accepted as a business philosophy. Unlike traditional marketing, the arts marketing cannot contain pre-marketing activities before the production of the good. Artistic creation and arts marketing are independent activities. Arts marketing find and develop audiences/customers without affecting artistic results. Arts marketing has an important role to bring together the artworks that artists create as they wish and buyers/ audiences and society in general. Although there is still some distance between the two fields, the marketing activities are being used increasingly in the world of arts.

keywords: arts marketing, art market, arts management, marketing in the arts

* Birinci yazarın "Sanat ve Pazarlama: Türkiye'deki Sanat Galerilerinde Pazar Odaklıık ve Performans iliş̧kisi" başlıklı doktora çalışmasından hazırlanmıştır. 


\section{Résumé}

\section{Le mariage " étrange " de l'art et le marketing}

Cette recherche examine la commercialisation des arts en association avec la discussion historique dans le domaine. Par conséquent, elle envisage à atteindre une définition plus concrète du marketing des arts en spécifiant ses différences du concept du marketing traditionnel. Dans ce contexte, la relation contradictoire entre les arts et le marketing du passé et la relation attrayante, provocatrice et ordinaire d'aujourd'hui seront discutées. On conclut que le marketing des arts a été vu avant comme une série des techniques et des processus des décisions. Cela a changé et aujourd-hui, le marketing des arts a été accepté comme une philosophie d'entreprise. Par rapport au marketing traditionnel, le marketing des arts ne peut pas inclure les activités de marketing avant la conception et la production du produit. La création artistique et le marketing des arts sont des activités indépendantes. Le marketing des arts trouve et développe des audiences et des clients sans effectuer des résultats artistiques. Le marketing des arts joue un rôle important comme il relie les oeuvres des artistes avec les audiences, les spectateurs, les acheteurs et avec la société. Même s'il existe toujours une certaine distance entre ces deux champs, les activités du marketing sont utilisées de plus en plus dans le monde des arts.

mots-clés: marketing des arts, marché de l'art, la gestion des arts, marketing dans les arts

\section{Özet}

Bu çalışma sanat ve pazarlama birlikteliğini tarihsel süreçte yaşanan tartışmalar ışığında incelemekte ve "sanat pazarlaması"nın geleneksel pazarlamadan farklarını belirleyerek doğru tanımlara ulaşmayı hedeflemektedir. Bu kapsamda geçmişte aykırı bir birliktelik olarak görülürken günümüzde daha çekici ve kabullenilir hale gelen sanat ve ticaret ilişkisi irdelenmektedir. Geçmişte bir dizi teknik ve karar verme süreci olarak görülen sanat pazarlaması günümüzde bir işletme felsefesi olarak kabul edilmeye başlanmıştır. Geleneksel pazarlamadan farklı olarak sanat pazarlaması faaliyetleri ürünün üretiminden öncesini içeremez. Sanatsal yaratım ile sanat pazarlaması birbirlerinden bağımsız faaliyetlerdir. Sanat pazarlaması sanatsal sonuçları etkilemeden izleyici/müşteri bulma ve geliştirme görevini yerine getirmektedir. Sanat pazarlaması sanatçının içinden geldiği gibi ürettiği sanat eserini alııı, izleyici ve genel olarak toplumla buluşturmada önemli bir rol üstlenmektedir. Günümüzde hala mesafeli yaklaşan bir kesim olsa da sanat pazarlaması faaliyetleri sanat pazarında aktif bir şekilde kullanılmaktadır.

anahtar kelimeler: sanat pazarlaması, sanat pazarı, sanat yönetimi, sanatta pazarlama 
Sanat maceracıdır, pazarlama güvenlidir; sanat beklenmeyeni arar, pazarlama tahmin edilebilir olanı arzular; sanat şaşırtıcı olanı ister, pazarlama rahat olanı; sanat organiktir, pazarlama yapaydır. Ama bizim ikisine birlikte ihtiyacımız var ve ikimiz de para kazanmak istiyoruz; ikimiz de en büyük izleyici kitlesini istiyoruz. Yapıcı bir şekilde birlikte yaşamaktan, birbirimizden öğrenmekten ve birbirimizi anlamaktan başka çaremiz yok (Tusa 1999: 120'den aktaran Ryan v.d. 2010: 214-215).

\section{Giriş}

Sanat ve ticaret ilişkisi çok eskilere dayanmakla birlikte sanatın doğası gereği tartışılagelen bir konu olmuştur. Tüm bu tartışmalara rağmen sanat pazarı günümüzde çok yüksek fiyatların konuşulduğu kendine has özellikleri olan, gelir ve istihdam yaratan bir pazar haline gelmiştir. Sanat pazarı, hem satış hem de yaratılan değer açısından özellikle son yıllarda dikkat çekici bir biçimde büyümektedir (Wang 2009: 1). Geçtiğimiz yıllar içerisinde, internet kullanımının yaygınlaşması ile artan çevrimiçi (online) satışlar, her yıl dünya çapında düzenlenen 260 'dan fazla sanat fuarının yarattığı rekabet, sanat yatıımcılarının ve yatırım fonlarının artması pazarın yapısını değiştirerek sanat pazarını etkileyen önemli gelişmelerdir (Ehrmann 2011: 5-6).

Günümüzde sanat pazarı sanatçılar, sanat izleyicileri/alıcıları/ koleksiyonerler, küratörler, sanat eleştirmenleri, sanat danışmanları, sanat galerileri, müzaye de evleri ve müzelerin yanı sıra sanat fuarları ve bienaller gibi pek çok temel aktörden oluşmaktadır. Sanat galerileri, müzayede evleri gibi sanatın kitlelere ulaştııımasında aracılık eden işletmelerin yaşamlarını sürdürebilmeleri, geleneksel ticari işletmeler gibi kâr elde ederek başarılı olmalarına bağlıdır. Bu intiyaç karşısında sosyal bilimlerin sanata ve kültüre karşı olan ilgisi artmış ve kültürel sosyoloji, kültürel ekonomi ve sanat pazarlaması gibi yeni disiplinler gelişmiştir. Pazarlama alanındaki araştırmacılar, sanatta pazarlamaya olan intiyacı çok çabuk fark etmekle birlikte diğer alanlarda başarılı ve verimli olduğu kanıtlanan pazarlama yöntem ve teorilerinin her zaman ve her şekilde kültürel ve yaratıcı endüstrilerde kullanıma uygun olmadığını da anlamışlardır. Böylece, sanat pazarlaması olarak adlandıılan ayrı bir çalışma alanı ortaya çıkmıştır (Kerrigan v.d. 2009: 203).

Bu makale sanat ve pazarlama birlikteliğini tarihsel süreçte yaşanan tartışmalar ışı̆̆ında incelemekte ve sonuç olarak sanatta pazarlama ya da "sanat pazarlaması"nın geleneksel pazarlamadan farklarını belirleyerek doğru tanımlara ulaşmayı hedeflemektedir.

\section{Sanat ve Ticaret İlişkisi}

Tarihsel olarak bakıldığında sanat ve ticaret ilişkisine olumlu yaklaşanlar yanında bu ilişkiyi eleştirenler de olmuştur. Sanat eserlerinin ticari anlamda değer kazanmasının 17. yüzyılda tüccarların, sergilerin ve müzayedelerin sanat 
ortamının temel unsurlarını oluşturduğu Hollanda'da gerçekleştiği belirtilmektedir. Sanata ilginin aristokrat ve kentsoylu kesimler arasında yaygınlaştığı 18. yüzyılda ise Avrupa kültür yaşamının merkezi Fransa olmuştur. Böylece sanat eserlerine olan talep artışı, sanatta aracıların varığını kaçınılmaz kılmıştır. Fransız İhtilali sonrasında ise parası olan herkesin resim alabildiği daha demokratik bir sanat ortamı oluşmuştur. 18. yüzyılda Londra müzayede evlerinin, sergilerin, aracı ve koleksiyonerlerin içinde yer aldığı önemli bir sanat pazarına dönüşmüştür. Ekonomik, toplumsal ve siyasal alanda ilerlemeler kaydeden Ingiltere'de güçlenen varlıklı sınıf, sanata yoğun ilgi göstermiş, dönemin en önemli koleksiyonerleri bu sınıfın içinden çıkmıştır. 19. yüzyıl sanayi devrimi ile birlikte saray, din ve tüm diğer kurumların değişim yaşadığı, bireyselliğin ön plana çıktığı, sanatsal üslup, üretim ortamı ve modellerinin değiştiği bir dönem olarak nitelendirilmektedir. 20. yüzyılın ikinci yarısında ise teknolojik gelişmeler, sanatsal yaratıcılığın temel motivasyonlarından biri, hatta en önemlisi haline gelmiştir (Demirdöven ve Ödekan 2008: 4).

Görüldüğü üzere sanatın ticarileşmesi çok eskilere dayanmaktadır. Ancak sanatçılar başta olmak üzere sanat dünyası, aristokratların ve monarşinin sanattan desteğini çektiği 18. yüzyıl ortalarından beri sanat-para ilişkisine eleştirel gözle bakmakta, sanat ekonomisini genellikle kabul edilemez görmekte ve mali kazanca yönelme eğilimini küçümsemekte ya da inkâr etmektedirler (Thompson 2011: 271; Stallabrass 2010: 104).

Günümüzde de bazı sanatçılar, sanatın sadece sanatsal değerinden ötürü değil bir statü ifadesi haline gelmesinden dolayı satın alınmasına ve oluşan pazar ekonomisine karşı tepkilidir. Buna rağmen çağdaş sanat dünyasının var olabilmesi için finansal kaynak önemli bir gerekliliktir. Dolayısıyla sanatçılar, bir eserin değerinin sıklıkla koleksiyonerin banka hesabı büyüklüğüne göre belirlendiği, statü ve yatırım amaçlı sanat tercihlerini kabul etmek durumunda kalmaktadırlar (Thompson 2011: 271). Bunun yanında sanatın toplumsal faydaları (toplumun sanat zevkini geliştirme, turist ve yatırım çekme gibi) nedeniyle devlet tarafından parasal olarak desteklenmesi de tartışılan bir konudur (Thompson 2011: 272).

Stallabrasss (2010: 14) serbest ticaret ve özgür sanatın birbirlerine göründükleri kadar zıt olmadıklarını savunmaktadır. Sanat, ekonomideki gelişmelerden kısa sürede etkilenir, kitlesel üretimden bunalan tüketicilere farklılaşma imkânı sunar ve bu anlamda serbest ticaretin yaralarını saran, bütünleyici bir parçasıdır. Atikoğlu da (2010: 31) kültür ve ekonomi ilişkisinin başından beri birlikte gittiğini, bir dönem ekonomin arkasında kalan kültürün 20 . yüzyılda ekonomiyi yakaladığını, son zamanlarda düşüş yaşayan ekonominin önüne geçerek daha da önem kazandığını belirtmektedir. Eskiden güç ve seçkincilik üzerine kurulu olan sanat artık bir anlamda demokratikleşerek ticari bir ürün haline gelmektedir. UNESCO verilerine göre, kültürel miras, görsel ve sahne sanatları, yazılı ve görsel medya, animasyon, internet, video oyunları, tasarım, reklamcılık ve mimarlıktan oluşan yaratıcı endüstrinin dünyadaki büyüklüğü 1,3 trilyon dolara 
ulaştı. Dünya GSMH'sının yüzde 8'ini oluşturan yaratıcı endüstri yüzde 10 ile en fazla büyüyen sektör ve uluslararası ticarette büyüklüğü 445 milyar dolara ulaşan alanın en önemli temsilcileri ise İngiltere, ABD ve Çin'dir (Ertürk, 2011).

Sanat ve ticaret ilişkisi üzerine yapılan bu tartışmalar sanat pazarına da yansımaktadır. Horowitz'e göre (2011: 8) sanat pazarı kendi içinde ikilemler barındırmaktadır. Nesnel bir bakışla değerlendirdiğimizde, sanat eserini yaparken kullanılan malzemelerin maliyetinin ve eseri yapmak için harcanan zamanın ötesinde sanatın gerçek değeri çok fazla değildir. Hatta sanat bazen ticari olmayan ve değer biçilemez bir nesne olarak görülmektedir. Diğer taraftan, sanat çok büyük bir sembolik ve ticari değer yaratabilmektedir. İşte bu zıtlıklar nesillerdir sanat eleştirmenlerini uğraştırmakta ve şaşırtmaktadır. Ancak günümüzde piyasada çok eski ya da tarihi değeri olmayan eserler için daha önce hiç görülmemiş yüksek fiyatların oluşması ve sanata yapılan yatııımların artması bu tartışmaları sanatın ticari yönüne doğru yöneltmiştir. Robertson'a (2005: 3) göre sanatçı tarafından yaratılan bir sanat eseri sanat pazarında ticarete konu olduğunda ticari bir ürün haline gelmektedir. Demirdöven ve Ödekan da (2008: 10) sanat galerilerinde ve sanat müzayedelerinde satışa sunulan eserlerin ve beraberinde sunulan hizmetlerin tamamının ticari bir faaliyete konu olduğundan ürün olarak adlandırıması gerektiğini belirtmektedirler.

Velthuis'a (2005: 24) göre sanat pazarı bünyesinde sanat mantığı ve kapitalist pazar mantığı olmak üzere birbiriyle çelişen iki mantık barındırmaktadır. Sanat mantığı değeri ölçülemeyen sembolik, yaratıcı veya anlamlı ürünlerin yaratımasını temel alan nitel bir mantıktır. Kapitalist pazar mantığı ise tersine; metalaştırma ve ölçümleme üzerine kurulu nicel bir mantıktır. İşte bu iki mantık arasında ortaya çıkan çatışma sanat pazarını ilginç ve farklı bir pazar haline getirmektedir.

Sonuç olarak, tarihte hiçbir zaman tam olarak anlaşılamayan sanat ve ticaret ilişkisi günümüzde çekici, kışkırtıcı ve sıradan yeni bir birlikteliğe dönüşmüştür. 2000 'li yıllardan sonra sanatta yaşanan yükseliş sürecinde, sanat pazarı sanatçılar, koleksiyonerler veya kurumlar onuruna düzenlenen kumsal partilerinden, küratörlüğü yapılmış yatlarda özel katıımlı akşam yemeklerine, ulaşılması zor ve özel yerlerde yapılan sanat satışları ve eğlencelerine kadar bir dizi faaliyeti kapsar hale gelmiştir. Sanat, mimari ve tasarım arasındaki işbirlikleri ile özel tasarım olan çok özel tüketim ürünleri ortaya çıkmıştır (Horowitz 2011: 6-7).

\section{Sanat Pazarı}

Sanat pazarı, özellikle de çağdaş sanat pazarı üreticilerin çoğu kez eserlerini öncelikle satış yapmak amacıyla üretmediği, alıcıların çoğu kez aldıkları eserin değeri ile ilgili kesin bir fikir sahibi olmadığı ve aracıların çoğu kez hiç görmedikleri eserlerin satışı için, belki de daha önce hiç sanat eseri almayan alıcılardan para talep ettiği bir pazar özelliği gösterir (Plattner 1998: 482). Yani diğer ticari 
ürünlerden farkıı olarak insanların değerinden emin olamadıkları nesneleri almak için önemli miktarlarda para harcadıkları ve sanatçıların az sayıda insanın almaya istekli olduğu bu ürünleri yapmak için önemli miktarda zaman harcadıkları bir pazardan bahsedilmektedir (Plattner 1998: 491).

Sanat pazarının, kitlesel ölçekte üretilmiş ürünlerden farklı olarak, benzersiz ya da nadir eserlerin alım-satımına bağlı ve mekanik reprodüksiyonu reddeden kendisine özgü bir ekonomisi vardır. Reprodüksiyonun mümkün olduğu sanat dallarında dahi sanatçılar tarafından belirlenen bilinçli sınırlar vardır. Sanat eserlerinin alıcıları fazla olmadığından, satıcıların kim oldukları bilindiğinden ve eserlerin arzı sınırlı olduğundan ticari sanat dünyası sıra dışı bir pazardır (Stallabrass 2010: 13-85-95).

Pek çok sanat eserinin bir eşi daha olmadığından bu pazarda arz kanunları değil "ya hep ya hiç" kanunu işlemektedir. Bu durumda tekel konumundaki bir sanatçıdan eşsiz bir sanat eseri satın alınırken, başka hiçbir nesneyle kıyaslama yapmak mümkün olmadığından, bu alışverişte güvenilir bir pazar bilgisinden yararlanmak da söz konusu olmamaktadır (Stallabrass 2010: 97).

Bu özelliklere ek olarak, sanat pazarı, koleksiyonerlerin hedonik veya finansal sebeplerle sanat ürünleri satın almasının yarattığı maddi etkinin yanı sıra karşılıkı iyilik yapma ve hediyeleşme sistemi ile de şekillenmektedir. Galeriler sanatçıları desteklemekte, sanatçılar galerilere eser bağışlamakta, koleksiyonerler bazen bir sanatçıyı veya bir galeriyi desteklemek için eser satın almaktadırlar (Velthuis 2005: 75).

Sanat pazarı, sanatın kültürel bağlamdaki konumu gereği diğer sektörlerden farklı olarak ekonomik öğelerin yanı sıra toplumsal bir misyon da üstlenmektedir (Açıkgöz 2011: 72). Dolayısıyla sanat pazarının varlığından söz edebilmek için hem kültürel hem de ekonomik sermayeye intiyaç vardır. Kültürel sermaye bir grup insanın sahip olduğu, sanatı benimseme, sevme ve ilgilenme ile ilgili sermaye olarak tanımlanabilir. Sanat eseri koleksiyonu yapmayı ve sanat galerilerinden eser satın almayı benimsemek sadece kültürel sermayeye değil aynı zamanda satın alma gücüne de bağııdır (Önsal 2006: 95-96).

Velthuis (2005: 20) sanat pazarını, fiyatların değişken ve düzensiz olduğu, aktif alıcı ve satıcıların sayısının az olduğu, pazarın gayri safi milli hasılaya katkısının kesin olarak bilinemediği, aslında kapitalist ekonominin bir parçası olan ama bir o kadar da uzak duran bir pazar olarak tanımlamaktadır. Sanat pazarının kendine özgü tüm bu özellikleri onu diğer pazarlardan ayıran yapısını ortaya koymaktadır.

\section{Sanat ve Pazarlamanın Birlikteliği}

Bilindiği üzere pazarlama insan istek ve intiyaçlarının değişim (mübadele) yoluyla karşılanması ve böylece müşteri tatmini ve sadakati yaratılması sürecini 
ifade eder. Sanat ile pazarlamanın birlikteliğinden doğan sanat pazarlaması, son yıllarda üzerinde çok durulan bir konu haline gelmiştir. Sanat sektörü ile ilgili birçok çalışma sanat pazarlamasının kâr amacı gütmeyen sektörde doğduğunu kabul etmektedir (Scheff ve Kotler 1996; Rentschler, 1998; Lee 2005; Bernstein 2007).

1980'lerin sonundan itibaren yaşanan ekonomik durgunluk, kurumların bağış önceliklerinin değişmesi, devletin sanata ayırdığı kaynakları kesmesi ve destek alabilmek için rekabet eden kâr amacı gütmeyen organizasyon sayısının artması sanat organizasyonlarının parasal kaynaklarını azaltmaya başlamıştır (Scheff ve Kotler 1996: 29). Boorsma ve Chiaravalloti'ye (2009: 3) göre 1980'li yıllar özellikle kâr amacı gütmeyen sanat organizasyonlarının, kâr amacı güden işletmelerin yönetsel uygulama ve ideolojilerine ilgi göstermeye başladığı bir dönem olmuştur. Bu yönelimin sebebi Scheff ve Kotler'ın da (1996) belirttiği üzere sanat galerilerinin davranışlarında daha hesap verebilir olmaları, kamu desteğine daha az bağımlı olmaları, izleyici katııımını arttırmaları ve eğlence sektörü ile rekabet etmeleri yönündeki baskının artmasıdır.

Diğer taraftan sanatsal etkinliklere katılma eğilimlerinde de bazı değişimler yaşanmaktadır. 1990'lara kadar özellikle gösteri sanatları organizasyonlarında çok güçlü olan üyelik sistemi, 1990'ların sonlarından itibaren değişen yaşam tarzları ve insanların boş zamanlarında katılabilecekleri alternatiflerin çoğalması sebebiyle zayıflamıştır (Bernstein 2007: 11-12). Günümüzde insanlar eğlence ve boş zaman alternatifleri seçerken bütün bir yılı önceden planlamak yerine daha kendiliğinden hareket etmek istemektedir. Insanların boş zamanının eskiye göre azalması ve daha uygun ve ekonomik eğlence çeşitlerinin ortaya çıkması rekabeti arttırmıştır (Scheff ve Kotler 1996: 29). Ayrıca günümüzde bir sanat organizasyonu için, farklı müşteri bölümlerini ve sanat etkinliklerine katılım konusunda farklı tutumları olan müşterileri sürekli memnun etmek gitgide zorlaşmaktadır. Bazı katıımcılar bir sanat etkinliğine katıldıklarında yeni bir şeyler öğrenip, meşgul olmak isterken, bazıları daha pasif deneyimler tercih eder. Kimi alışılmadık farklı sanatlara yönelirken, kimi alışıımış çalışmaları tercih eder. Bunlar yanında, katılmak isteyip de çeşitli nedenlerle sanat katılımından uzak kalan bir kesim ile gene çeşitli sebeplerle katılmak istemeyen başka kesimler söz konusu olabilir. Eğitim seviyesi de sanat katılımını etkileyen önemli sosyo-ekonomik faktörlerden biridir. Ancak eğitim sistemi içerisinde sanat eğitiminin yetersizliği gençlerin sanatı benimsemesine engel teşkil eden bir durumdur. Sanat katıımına önemli bir engel olarak görülen fiyatın ise son yıllarda yapılan araştırmalarda hem katılımcılar ve hem de sanat etkinliklerine katılmayan kişiler açısından çok da etkili olmayan bir faktör olduğu bulunmuştur. Son olarak gelişen teknoloji ile birlikte, tüketicilerin kendilerine sunulan deneyimlerin daha fazla bireyselleştirilmesine yönelik beklentileri artmıştır (Bernstein 2007: 11-14).

Dickman'a (1997: 4-5) göre sanatta pazarlamaya olan ilginin itici gücü tüketiciler, devlet, sponsorlar ve rekabet olmuştur. Yukarıda belirtildiği üzere günümüzde tüketiciler boş zamanlarını ve isteğe bağlı gelirlerini harcamak için 
daha fazla seçenekle karşı karşıyadırlar. Seçeneklerin artması ile tüketiciler sanat işletmelerinden daha fazla şey beklemekte buna karşın işletmelere daha az sadakat göstermektedirler. Devletler eskiye göre harcamalarını kısmakla birlikte hala sanatın en büyük destekçileri konumundadırlar. Birçok ülkede devlet sanat yöneticilerinin yönetim becerilerini geliştirmek amacıyla özellikle pazarlama alanında programlar düzenlemektedir. Devletler sanat ve kültür programlarını desteklemeye devam etmekle birlikte, kâr amacı gütmeyen sanat işletmelerinin daha katılımcı veya ticari sponsorlukları arttırarak finansal olarak daha etkin olmalarını ve kendi kaynaklarını geliştirip yönetmelerini beklemektedirler. Ekonomik durgunluk zamanları ticari sponsorlukların zorlaştığı dönemlerdir. Sanat işletmesi belirli bir beklenti ile sponsor ararken, sponsorluk yapacak işletmeler de bu sponsorluğun kendi işletmelerine katkı yapmasını beklerler. Karşııklı bu beklentiler de rekabetçi bir ortam oluşturmaktadır (Dickman 1997: 4-5). Tüm bu gelişmeler ve değişimler sanat sektöründe pazarlamaya olan ihtiyacı arttırmıştır.

Sanat pazarlamasının gelişiminden bahsederken paralel bir gelişim izleyen sanat yönetimine de değinmek gerekmektedir. 1960'larda ortaya çıkan sanat yönetimi çok disiplinli yapısı ile karmaşık bir kavramdır. Çıkış noktası kâr amacı gütmeyen sanat organizasyonları olan sanat yönetimi günümüzde yaratıcı endüstride faaliyet gösteren diğer ticari organizasyonları da kapsar hale gelmiştir (Chong 2010: 1). Sanat yönetimi yönetim, pazarlama, sosyoloji, estetik, ekonomi ve hukuk gibi birçok disiplinin bir arada olduğu bir alandır (Rentschler ve Shilbury 2008: 60). Sanat yöneticileri bir sanat işletmesinde planlama, organizasyon, yöneltme ve denetim gibi yönetim fonksiyonlarını uygularken; planlama ve geliştirme, pazarlama ve halkla ilişkiler, insan kaynakları yönetimi, finansal yönetim gibi temel işletmecilik fonksiyonlarını da yerine getirmektedir (Byrnes 2009: 15-18). Bir çalışma ve uzmanlık alanı olarak sanat yönetimi 1950'lilerden beri ABD ulusal politikasındaki değişimlerin bir ürünü olarak ortaya çıkmıştır. Politika değişiklikleri ile sanata verilen artan destek sanat pazarının gelişmesine katkıda bulunmuştur. Nüfusun ve eğitim seviyesinin artması sanat alanında yeni birçok iş alanı ve istihdam yaratılmasını sağlamıştır (Byrnes 2009: 53). Sanat yönetimi, 20. yüzyılın sonlarında özellikle yeterli bütçenin sağlanamaması ile zor duruma düşen gösteri sanatlarında yaşanan gelişmelerle önemini arttırmıştır. Modern sanat yönetimi kavramı 80'lerin başlarında ilk olarak ABD'de ve İngiltere'de, sonra Avrupa'da ilk akademik sanat yönetimi derslerinin konuya bilimsel açıdan da ışık tutması ile profesyonelleşmiştir (Bendixen 2010: 7).

Geçtiğimiz 30 yılda sanat yönetimi hakkındaki yayınlarda ciddi bir artış görülmüştür. Evrard ve Colbert'e göre (2000) teorik bir yapı olarak yönetim ile bir sektör olarak sanatın kesişimine yerleşen sanat yönetimi, diğer disiplinlerden farklı olması yanında köklerini aldığı disiplinden de farklı bir birikim oluşturmuştur. Ayrıca yeni bilgi, kavram ve teorilerin doğuşuna neden olarak genel yönetim bilgisine katkıda bulunmuştur. Yönetim alanındaki dergilerde sanat yönetimi ile ilgili makaleler yayınlanması, sanat yönetimi ile ilgili dergiler yayınlanması, özellikle bu yeni disipline odaklanan bilimsel konferanslar ve eğitim programlarının 
düzenlenmesi yeni bir disiplinin doğuşuna işaret etmektedir. Sanat yönetimi bir disiplin olarak konusu sanat olan, toplum içerisinde bir yeri olan, çeşitli perspektiflerden değerlendirilen, amaç ve yaklaşım açısından çeşitli alanlarla benzerlikler ve tamamlayıcılıklar gösteren bir alandır (Evrard ve Colbert 2000).

Sanat yönetiminin önemli bir parçası olan sanat pazarlamasının doğuşuna ilişkin Lee'nin (2005) yaptığı bir çalışmaya göre 1970 ve 80'lerde sanatta pazarlama, bir dizi teknik ve karar verme süreci olarak görülürken ilerleyen dönemde sanat pazarlaması bir yönetim felsefesi olarak kabul edilmeye başlanmıştır. 1990'lardan sonra sanat pazarlamasında ciddi gelişmeler olmuştur. Sanat organizasyonlarında pazarlama departmanları kurulmuş, sanat pazarlaması uzmanları ve danışmanları görev almaya başlamış, konu ile ilgili eğitimler, seminerler ve konferanslar yapılmaya başlanmıştır. Pazarlama akademisyenleri pazarlamanın sanat ve kültürel sektöre uygulanmasıyla ilgilenmeye başlamıştır. Bugün sanatta pazarlama, sadece pazarlamanın sanatta kullanımasından öte sanat pazarlaması şeklinde tanımlanır hale gelmiştir. Günümüzde sanat işletmeleri kendilerini tüketicinin perspektifinden görmeye ve müşteri ihtiyaçlarını karar verme süreçlerinin merkezine koymaya teşvik edilmektedirler (Lee 2005: 289-305).

Sanatın akademik bir çalışma alanı olarak gelişmesine paralel olarak sanat pazarlaması literatürü de araştırmalarla zenginleşmiştir. Rentschler (1998; 2002) sanat yönetimi ve pazarlaması alanındaki yedi hakemli dergide yayınlanan akademik çalışmaları içerik analiziyle incelemiştir. Sanat pazarlamasının çeşitli yönleri ile ilgili toplam 171 makale çerçevesinde sanat pazarlamasının gelişimini üç aşamada inceleyen çalışmaya göre sanat pazarlaması makaleleri 1970'li yıllarda ciddi bir şekilde artmıştır. Kronolojik sınıflandırmaya göre kuruluş aşaması (1975-1984) olarak isimlendirilen dönemdeki makaleler izleyici eğitimi, örgüt çalışanlarının izleyici araştırmalarının yararları hakkındaki farkındalıklarını arttırma ve sanatın ekonomik etkileri hakkında yazılmıştır. Bu dönem, kültürel organizasyonlarda değişim intiyacının ortaya çıktığı dönemdir. Böylece sanat işletmeleri pazarlamaya daha açık olmaya başlamışlardır. Bu dönemde bütünleşik stratejik sanat pazarlaması uygulamasının ilk örnekleri bütüncül (holistik) sanat pazarlaması yaklaşımının farkında olunmadan benimsenmiştir. Kısıtlı olan ilk uygulamalar reklam, duyurum gibi tutundurma etkinliklerine odaklanmıştır. Profesyonelleşme periyodu ise (1985-1994) pazarlamanın kâr amacı gütmeyen sanat organizasyonlarına uygulanabilirliğinin tanındığı ve sanat organizasyonlarında pazarlama departmanlarının kurulduğu dönemdir. Bu dönem, uzmanlıkların, ilgili yeteneklerin ve pazarlama departmanlarının geliştiği dönemdir. Böylece pazarlama departmanları profesyonelleşmiştir. Sanat pazarlamasının organizasyonel uygulamasında bilinçli ama kısıtlı bir bütünleşme sağlanabildiği görülmektedir. Üçüncü aşama olan keşif periyodu (1995-2000), pazarlama felsefesinin sanat organizasyonlarına yerleşmeye başladığı bir dönem olmuştur (Rentschler 1998). Bu dönemde, sanat organizasyonlarının standart işletim (operasyon) süreçleri artık pazarlamayı da içermektedir (Rentschler 2002: 13). 
Tablo 1: 1975 'ten $2000^{\prime}$ e sanat pazarlaması çalışmalarının özellikleri

\begin{tabular}{|c|c|c|}
\hline $\begin{array}{l}\text { Kuruluş Dönemi } \\
\text { (1975-1984) }\end{array}$ & $\begin{array}{l}\text { Profesyonelleşme Dönemi } \\
\text { (1985-1994) }\end{array}$ & $\begin{array}{l}\text { Keşif Dönemi } \\
(1995-2000)\end{array}$ \\
\hline $\begin{array}{l}\text { İşletme odaklı bilgi toplama } \\
\text { çalışmaları }\end{array}$ & $\begin{array}{l}\text { Strateji ve etkinlik odaklı } \\
\text { çalışmalar }\end{array}$ & $\begin{array}{l}\text { Hizmetlere örgütsel yaklaşım } \\
\text { stratejileri }\end{array}$ \\
\hline Öğrenme uygulamaları & Pazarlama uygulamaları & Deneyim odaklı pazarlama \\
\hline Satış odaklı & Pazarlama odaklı & $\begin{array}{l}\text { Estetik deneyimde stratejik } \\
\text { pazarlama }\end{array}$ \\
\hline Gelir & & Çeşitlendirme \\
\hline Demografik çalışmalar & Psikografik çalışmalar & İşbirlikçi çalışmalar \\
\hline $\begin{array}{l}\text { Pazarlama uygulamaları } \\
\text { önemsenmemiş }\end{array}$ & $\begin{array}{l}\text { Çeşitli pazarlama modelleri } \\
\text { önerilmiş }\end{array}$ & $\begin{array}{l}\text { Pazarlama stratejisine bütüncül } \\
\text { (holistik) yaklaşım }\end{array}$ \\
\hline Etkinlik karması & Pazarlama karması & Topluluk karması \\
\hline
\end{tabular}

Kaynak: Rentschler (2002: 12)

Rentscher (1998; 2002) tematik olarak sanat pazarlaması makale içeriklerini de analiz etmiştir. "Bir kültür olarak pazarlama" makaleleri kuruluş döneminde (\%64) baskın olmaktadır. Bu makaleler organizasyonların daha fazla müşteri odaklı olma ve onların ihtiyaçlarına cevap verme gereğini vurgulamaktadır. "Bir strateji olarak pazarlama" ise kuruluş dönemi makalelerinin sadece \%8'inde yer bulmaktadır. Keşif döneminde bu durum tersine dönerek makalelerin \%60'ı konumlandırma, örgütsel yön ve rekabet konularını işleyen strateji makaleleri olmuştur. "Taktikler olarak pazarlama" ise ürün, dağıtım, tutundurma ve fiyattan oluşan pazarlama karmasının belirli özelliklerine odaklanarak her üç dönemde \%30 ile sabit kalmıştır. Ancak bu makalelerin odaklandığı konular zamanla güncel pazarlama sorunlarını yansıtacak şekilde değişmiştir.

Rentscher'in kuruluş dönemi diye isimlendirdiği dönemden de öncesine bakıldığında, 1960'ların sonuna kadar kültürel sektörde pazarlama kelimesi çok nadir duyulmaktaydı. Sanat yöneticilerine iş dünyasında pazarlamacıların kullandığı teknikleri öneren çok kısıtlı sayıda çalışma vardı. Pazarlama akademisyenleri ve uygulamacıları kâr amacı gütmeyen sektörü önemsemezken, sanat yöneticileri ise pazarlamayı gereksiz hatta bir tehdit olarak görmekteydi. Kotler ve Levy'nin klasikleşen eseri "Broadening the concept of marketing (1969)" ile pazarlamacılar kâr amacı gütmeyen sektörün sorunlarını ve potansiyelini fark etmişlerdir (Gainer 1989: 147). Kotler ve Levy (1969) makalelerinde pazarlamanın diş macunu ve sabun gibi ürünleri satmaktan öte yaygın sosyal bir etkinlik olduğunu öne sürerek pazarlama kavramının daha geniş kapsamda kabul edilmesine öncü olmuşlardır.

Boorsma (2006: 73) sanat pazarlamasının 1980'lerden beri hızlı bir profesyonelleşme sürecinde olduğunu belirtmektedir. Günümüzün pazarlama yöneticileri mevcut pazarlama teorisi hakkında bilgi sahibidirler ve sanat pazarlamasının sanat 
için stratejik öneminin farkındadırlar. Sanat pazarının yaygınlaşması bu alanda yapılan akademik çalışmalardaki artışla da desteklenmektedir. Bu konuda birçok kitap yazılmıştır (Örneğin, "Marketing the arts" Mokwa, Dawson ve Prieve 1980; "Art marketing handbook: marketing art in the nineties" Goodman 1991; "Marketing the arts" Blackall ve Meek 1992; "Arts marketing" Diggle 1994; "Creative arts marketing" Hill v.d. 2003; "The art firm: aesthetic management and metaphysical marketing" Guillet de Monthoux 2004; "Arts marketing" Kerrigan v.d. 2004; Kolb 2005; Bernstein 2007, Micocci 2008; O'Reilly ve Kerrigan 2010) ve akademik dergilerde artan sayıda makale yayınlanmaktadır. Son 20 yılda, sanat alanında "kirli" bir kelime olarak algılanan sanat pazarlaması marjinal bir konu olmaktan çıkıp uğraşı alanına dönüşmüştür. Tutundurma faaliyetlerine (reklam, kişisel satış, halkla ilişkiler duyurum, satış promosyonları) odaklanan sanat pazarlaması zamanla gelişerek ilişkisel pazarlama, deneysel pazarlama, pazar bölümleme, izleyici güdüleri ve fiyatlandırma gibi konuları kapsar hale gelmiştir (Rentschler 2007: 91). Sanatta pazarlama ilk tartışılmaya başlandığı zamanlarda işlevsel bir araç olarak görülürken yıllar içerisinde bir işletme felsefesi haline gelmiştir (Boorsma ve Chiaravalloti 2009: 2).

\section{Sanatın Pazarlanması Hakkındaki Tartışmalar}

Sanat ve pazar arasındaki ilişki oldukça karmaşıktır. Dolayısıyla sanat pazarlaması alanında çalışanlar, geleneksel bir ürünün pazarlanmasında aynı şekilde veya aynı derecede ortaya çıkmayan bir dizi konuya özen göstermek durumundadırlar. Öncelikle sanatın tanımlanmasının çok zor olması sanat pazarlamasının tanımlanmasını da zorlaştırmaktadır (Kubacki ve O'Reilly 2009: 55). Boorsma'ya (2006: 75) göre sanatsal yaratım ve sanat pazarlaması kendilerine ait bir mantıkları ve sorumlulukları olan bağımsız işlerdir. Sanat pazarlaması sanatsal sonuçları etkilemeden ve değiştirmeden izleyici bulma ve geliştirme görevini yerine getirmektedir (Boorsma 2006: 75). Fillis'e (2002: 133) göre sanat pazarlamasında önemli olan pazarlamanın nasıl uygulandığıdır. Müşterinin isteklerine dayalı olarak mı pazarlama prensipleri uygulanıyor yoksa kendi pazarını yaratarak yeni sanatsal bir ürün için talep mi oluşturuluyor? Pazarlama temel olarak müşteri istek ve ihtiyaçlarının göz önüne alınması gerektiğini savunur. Ancak sanatçının ve galerinin her zaman müşterinin istediğini üretmesi durumunda sanatsal fikir ve uygulamaların yaratıcı gelişimini sürdürmek mümkün olmayacaktır.

Kotler ve Scheff (1997: 34) sanat organizasyonlarının tüketicilerin tercihlerini, memnuniyet seviyelerini, istek, ihtiyaç, algı ve tutumlarını sistematik olarak araştırmalarını ve sundukları hizmetleri geliştirmek amacıyla bu bilgiler üzerine hareket etmelerini gerektiren müşteri odaklı yaklaşım önermektedir. Ticari işletmelerde başarısı kanıtlanan müşteri-değeri yaklaşımının sanatsal misyon sınırları içerisinde uygulandığı sürece sanatın pazarlamasında en iyi yaklaşım olduğunu öne sürmektedirler. Ancak Kotler ve Scheff (1997: 34-36) müşteri odaklı yaklaşımın sanat eserinin kendisine değil, ürünün tanıtımı, fiyatlandırması, paketlenmesi ve dağıtımı gibi bileşenler açııından uygulanmasını önermektedirler. 
Sanat pazarlamasının rolü sanata katılımı ve fonları arttırarak sanat organizasyonun sanatsal misyonunu gerçekleştirmesine dolaylı olarak destek olmaktır. Colbert'a (2003: 31) göre sanatsal bir ürün bir pazar intiyacını karşılamak üzere yaratılmaz. Dolayısıyla sanat pazarlaması istedikleri bir ürünü sunarak tüketicilerin ihtiyaçları karşılamak yerine bu üründen etkilenen, bu üründen hoşlanan tüketicileri bulmaya çalışır. Bu da sanat pazarlamasını geleneksel pazarlamadan ayıran en önemli farktır. Şekil 1'de kültürel işletmeler için Colbert'in önerdiği pazarlama modeli yer almaktadır. Hayes ve Roodhouse'a (2010: 40) göre de sanat pazarlamacıları temel ürünün değerlerine veya yaratıcı sürece meydan okuma riskine girmek yerine zenginleştirilmiş ürüne uyarlamalar yapmaya odaklanarak müşteri memnuniyetini sağlamaya çalışmaktadırlar.

Şekil 1: Kültürel işletmeler için pazarlama modeli

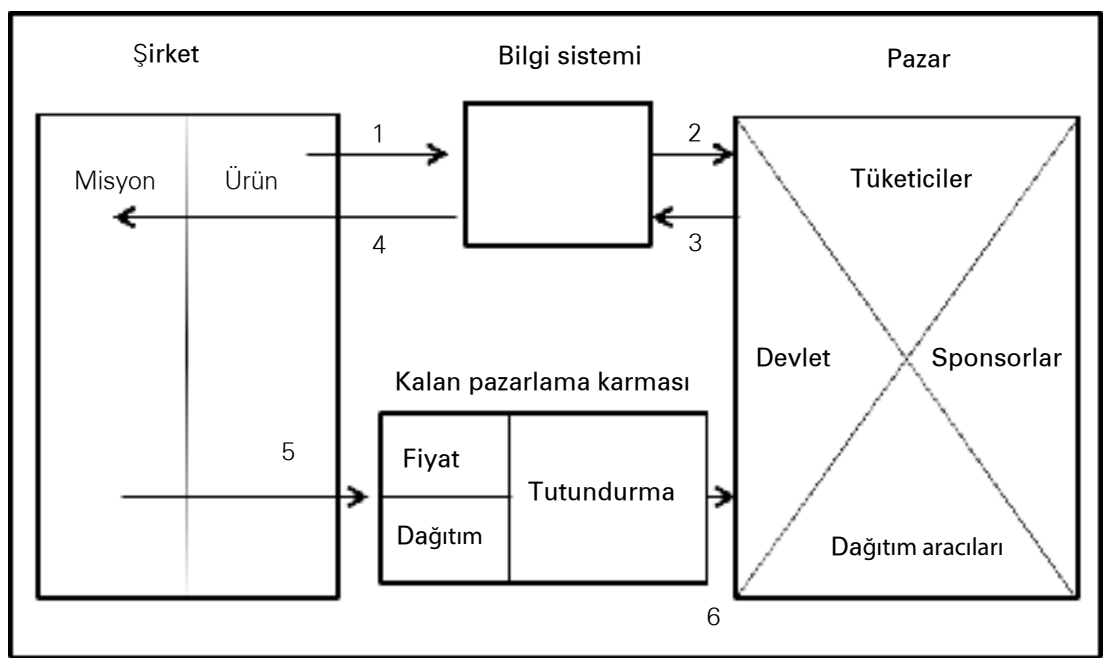

Kaynak: Colbert, (2003: 3)

Bu sebeplerle pazarlamanın rolünü, üretilen sanatın çeşidini etkilemek değil yalnızca sanatçının kreasyonlarını ve yorumlamalarını uygun seyirci ile eşleştirmek olarak tanımlayan çalışmalar vardır (Mokwa v.d. 1980). Bu tanım, sanat pazarlamasını uygun sayıda insanı uygun iletişim kanallarıyla sanatçı ile bir araya getirmek olarak tanımlayan Diggle (1994) tarafından da tekrar edilmiştir. Bu bakış açısıyla, sanat pazarlaması üründen önce başlayıp pazar talebine cevap vermek yerine, ürün için müşteriler bulan özel bir pazarlama olarak görülmektedir (Hill, O'Sullivan ve O'Sullivan 2003: 2-3).

Sanat pazarlaması literatürü sanatın, en üst insan ihtiyacı olan kendini gerçekleştirmenin önemli bir parçası olduğunu savunmaktadır (Robertson 2005: 34). Sanat pazarlamacılarının amacı ürünü takdir etmesi olası müşteriler bulmak ve 
onlarla iyi ilişkiler kurmaktır. Bir diğer önemli amacı ise sanata ilgisiz insanları teşvik ederek onları sanat tüketicileri haline getirmektir. Bu grup için, pazarlamacılar tarafından ortaya çıkarılan ihtiyaçlar, tüketicilerin gerçek tercihlerinden çok uzak olmasına rağmen, onları sanata karşı gizli intiyaçları olduğuna ikna etmek ve sonra bu intiyaçlarını gidermeye teşvik etmek gerekmektedir (Lee 2005: 300). Sanat pazarlaması literatürüne göre pazarlamacılar sanat tüketicileri için seçenekleri ve sanat deneyiminin kalitesini arttırmaya çalışmaktadırlar. Sanat pazarlaması pazarlamayı sanat eserleri için uygulamaktadır (Chong 2010: 131). O'Reilly'e (2005: 574) göre sanat pazarlaması sanatın ve kültürel mirasın pazarlanmasına odaklanmaktadır.

Sanat pazarlamasının literatürde çeşitli tanımları bulunmaktadır. Sanat pazarlaması, kurumsal ve sanatsal amaçlara ulaşmak amacıyla müşterilerle değişim iliş̧kilerinin karşılıklı olarak tatmin edilmesini bir araç olarak gören bütünleşik bir yönetim sürecidir (Hill v.d. 2003: 1). Sanat pazarlamasının amacı, mümkün olan en geniş sosyal geçmiş, ekonomik durum ve yaş aralığındaki yeterli sayıda insanı, sanatçı ile uygun ortak bir iletişim platformuna getirmektir. Bunu gerçekleştirirken de en iyi finansal getiriye ulaşmayı amaçlar (Diggle 1994: 25). Bir başka tanıma göre sanat pazarlaması, üretilen sanatsal değeri sanatçıdan halka iletmede ortaya çıkan sanatsal potansiyeli arttırmak ve/veya meydana gelen çıktıyı geliştirmeye çalışmak amacıyla sanat organizasyonları tarafından yapılan hizmetleri içermektedir (Botti 1999: 28).

Sanat pazarlaması sanat dünyası ile işletme yönetimi dünyasının bir araya gelmesinden oluşmaktadır. Birbirine zıt bu iki dünyadan biri daha önce mevcut olmayan yeni bir şeyi üreten insan yaratııılığından, diğeri mevcut işletme dünyasının uygulamalarından oluşmaktadır. Sanat bütünlüğe (holistik) dayalı iken, işletme dünyası analitiktir (Bendixen 2010: 3). Sanat yönetimi, kendi değerini kendi taşıyan sosyal etkinlikler alanı olarak sanatta ısrar ederse, ticari amaçlardan uzaklaşacak; bütçeler dâhilinde maddi kaynakları kullanmada ekonomik rasyonelliğin tarafını tutarsa sanatsal amaçlarla arası bozulacaktır (Bendixen 2010: 3). Ticari sonuçlar elde etmeyi amaçlayan pazarlamanın tüketici istek ve intiyaçlarına yönelik olması ancak kültürel ürünlerin doğası gereği sanatçının eserlerini böyle bir uyumluluktan bağımsız bir şekilde yaratmak intiyacında olması sanat ve pazarlama birlikteliğinde tartışılan bir konudur (Mokwa v.d. 1980). Dolayısıyla sanat pazarlaması ile ilgili belki de en önemli sorunlardan biri sanat pazarlamasının sanat organizasyonlarınca kabulüdür. Bazı sanatçı ve sanat organizasyonu çalışanları sanat pazarlamasını materyalist sonuçlara ulaşmak için kullanılan istismarcı ve etik dışı bir süreç olarak gördüğünden sanatta pazarlama olgusunu kabullenememektedirler (Hill v.d. 2003: 29-30). Hatta pazarlama perspektifini benimsemenin "sanatçının ruhunu satması anlamına geldiği" ya da "sanatsal bütünlüğünü gözden çıkardığı" süregelen tartışmalar arasındadır (Kerrigan v.d. 2004: 188). Ayrıca kâr amacı gütmeyen kuruluşların pazarlamayı, kamu desteğinin kaybı ve gereksiz bir masraf olarak görebilmesi ve pazar araştırmasını kullanışsız olarak algılayabilmeleri mümkündür. Pazarlamanın yeni 
tatlar geliştirmek veya standartları yükseltmek için çalışmak yerine pazar neyi talep ediyorsa sadece onu tutundurmaya çalıştığına dair eleştiriler vardır. Buna karşın sanat pazarlaması savunucuları pazarlama anlayışının, sadece kaynakların kullanımın geliştirilmesinde ve onları daha verimli ve hesap verilebilir bir şekilde işletmeye yardımcı olmada değil aynı zamanda izleyiciler ile nasıl ilişki kurulacağını stratejik olarak belirlemede sanat organizasyonlarının başarısına önemli bir katkıda bulunduğunu savunmaktadır (Hill v.d. 2003: 29-30).

Hirschman (1983) pazarlama kavramının, sanatsal üretim sürecini etkileyen kişisel değerler ve sosyal normlar yüzünden sanatçının felsefesi ve davranışıyla uyuşmadığını belirtmektedir. Sanatçılar esasen kendi güzellik, duygu veya diğer ideallerinin öznel kavramlaştırmalarını ifade etmek için yaratırlar (Becker 1978). Sanatsal yaratıcılık süreçteki temel etkidir ve müşterinin talebine cevap vermekten ziyade sadece kendi adına ifade edilir ve deneyimlenir (Holbrook ve Zirlin 1983'ten aktaran Fillis 2010: 34). Sanat pazarlamasının en önemli farkı üründen kaynaklanmaktadır. Fayda sağlayan diğer ürünler tüketiciler için üretilirken, sanatçı bir üretici olarak ürünü olan eserini aslında kendi için üretmektedir. Bazı sanat sektörü çalışanları için tanınmak ve itibar sanat eserinin satılmasından daha önemlidir. Bu durum idealizm ve ticari anlayış arasında bir çatışmaya neden olmaktadır (Fillis 2006: 31).

Dennis ve Macaulay'e (2010: 205) göre süregelen sanat ve ticaret tartışmasında, profesyonel sanatçı kavramı hayatın bir gerçeğidir ve her zaman da öyle olmuştur. Çalışmalarında, sanat ve ticaret arasında gözle görünen gerilimden doğrudan olarak en çok etkilenen insanlardan olan profesyonel müzisyenlerin bu konudaki görüşlerini araştırmışlardır. Sonuçlara göre müzik ve pazarlama arasındaki ihtilaf yanlış olsa bile, uygulamada bakan tarafın baktığı yere göre değişen bir anlayış sürmektedir. Ticari ve sanatsal bakış açıları gerçekten farklıdır ama birbiri ile savaşmak yerine birlikte var olmalıdır. Dennis ve Macaulay (2010: 210) müzisyenlerin sanatsal ve ticari başarı hedefleri arasında bir gerilim olup olmadığını, kendilerini pazar odaklı görüp görmediklerini ve öncelikle pazarlamanın ne olduğunu bilip bilmediklerini sormuşlardır. Araştırmacılar günümüzde Ingiltere'deki caz müzisyenlerinin sanatsal ve ticari anlayışları arasında çok fazla bir çatışma olmadığını ortaya koymuştur. Sanatsal ve ticari amaçlar arasındaki ilişki bir bozuk paranın iki yüzü gibidir. Birbirleriyle karşılaşamazlar ama düşman gibi birbirlerinin karşısında da duramazlar. Dennis ve Macaulay'e (2010: 213) göre sanatçılar sanatsal bütünlüklerinden taviz vermeden ticari olarak başarılı olabilirler. Ticari başarı mal satmak olarak görülmemelidir. Örneğin ünlü caz müzisyeni Miles Davis'in ticari başarısı tabii ki yaratıcılığı ve sanatsal becerisi ile mümkün olmuştur. Ancak bu başarı değişen kültürel yapıya cevap verme ve tahmin edebilme yeteneğine de oldukça bağlıdır. Bu çalışmada akademisyenlere, sanat-ticaret tartışmasını bırakarak bu iki alanın yan yana çalışabilmesinin yollarını bulmaları tavsiye edilmektedir. 
Kubacki ve Croft $(2004 ; 2006)$ çalışmalarında hem ürün üreten hem de bunu kendi müşterileri olan dinleyicilerle paylaşan sanatçılar olan müzikle uğraşan sanatçıların pazarlamaya karşı tutumlarını araştırmıştır. Sanatçıların tutumlarını şekillendirmede toplum, kültür ve ekonomik çevre gibi dış faktörlerden daha fazla sanatın kendisinin etkili olduğu bulunmuştur. Araştırmada müzisyenlerin pazarlamaya karşı bir ikilem içinde oldukları hatta bu ikilemin daha ileriye giderek "bir ticari iş olarak sanat" kavramına karşı antipatiye dönüşebildiği ortaya konmuştur. Kubacki ve Croft (2004) modern pazarlamanın klasik müzik ve cazı nasıl etkilediğine dair görüşleri hakkında müzisyenlerle nitel yaklaşımla görüşmeler yapmışlardır. Sonuçlar iki farklı bakış açısını ortaya koymaktadır. Araştırmaya katılan sanatçıların bir kısmı pazarlamayı müzisyenlerin sanatsal bütünlüğüne zarar vermekle suçlamakta, diğer grup ise pazarlamanın müziğe katkıları olduğuna ve daha iyi anlaşılması gerektiğine inanmaktadır.

Galerist İbrahim Demirel sanat galericiliğinde pazarlamanın rolüne ilişkin düşüncelerini şu şekilde ifade etmektedir:

"Ben bu işi gönülle yapıyorum. Hocalarımdan aldığım eğitim, disiplin, sanat aşkının verdiği güçle ayakta kalmaya çalışıyorum. Profesyonelce bir pazarlama yaklaşımım yok. Çünkü ben de sanatçıyım, tüccar değilim. Bugüne kadar özverili bir yaklaşımla bu işi yürüttüm, parayla değil. Sanata ve sanatçıya önem vererek işimi geliştirmeye çalıştım. Dolayısıyla pazarlama benim işim değil. Sanat eseri herhangi bir ticari mal gibi, örneğin, bir şampuan gibi pazarlanamaz ki. Şampuanı herkes alabilir ama sanat eserinin kısıtlı sayıda ve bilinçli alıcısı vardır; almak istediği eseri nerede, nasıl bulabileceğini bilir. Onun için sanat eserinin ticari bir malın pazarlanması gibi pazarlanacağını düşünemiyorum. Bu iş, hem alıcı hem satıcı için, biraz aşkla yapılan bir iştir, ticari mal pazarlamaya benzemez. Eserin doğru zamanda, doğru müşteriye, doğru fiyatla satılması önemlidir. Kısacası, bu işin en doğru pazarlama çözümü, sanat eseri sahipliği konusunda bilinçli galericisanatçı-alıcı üçgenidir" (Kişisel görüşme, 18 Mart 2011).

Hangi alanda olursa olsun her sanatçı benzer bir ikilem yaşamaktadır: En derin düşünce ve duygularının katıksız yaratıcı bir ifadesi olarak kendi ideal sanatsal bütünlüklerini mi izlemeliler yoksa insanlar tarafından tanınmak, tasdik edilmek ve ticari başarı kazanmak amacıyla hedef pazarlarını memnun etmeye mi çalışmalılar? Bazı görüşlere göre bu ikilem yüksek sanatsal kaliteden ödün vermeden popülerliğe ulaşarak çözülebilir (Addis ve Holbrook 2010: 141).

Fillis'e (2002: 140) göre "sanat sanat içindir" ve "sanat para içindir" felsefi tartışması sanat pazarlamasının ilerlemesi için bir engel değil yaratıcı değişim için bir katalizör ve yeni sonuçlar ortaya koyma, daha anlamlı ve uygun bir sanat pazarlaması teorisi ve uygulaması oluşturma fırsatı olarak görülmelidir. Meyer ve Even'a (1998: 279-280) göre sanat pazarının ekonomik yönlü görülmesi sıklıkla bir provokasyon olarak görülse de sanat ve pazarlama ikilem içinde değildir. Bir sanatçının pazarlama araçlarından faydalanması durumunda ticaretin sanat üzerinde hükmedici bir faktör haline gelebileceği korkusu yersizdir. Sanat pazarlamasının, sanatın özelliklerine saygı gösteren bir yapısı vardır ve sanatçılar 
aslında yüzyıllar boyunca pazarlamadan yararlanmıştır. Yaptıkları ampirik araştırma, tamamen kabul etmeseler de sanatçı ve galerilerin pazarlama faaliyetlerinde bulunduğunu göstermiştir. Sanatçılar eserlerini yarattıktan sonra, bu eseri almaya hevesli tüketicileri bulmaya ve teşvik etmeye çalışmakta ve pazarın yaptıkları esere etkisini reddetmektedirler.

Görüldüğü üzere sanat pazarlaması, sanat eserinin kendine özgü özelliklerinden ötürü farklılıklar barındırmaktadır. Bu anlamda sanat pazarlaması sanatçının içinden geldiği gibi ürettiği sanat eserini alıcl, izleyici ve genel olarak toplumla buluşturmada önemli bir rol üstlenmektedir.

\section{Sonuç}

Geçmişte sanatta pazarlama, sanat işletmesi yöneticileri tarafından halka ulaşmak için sanatsal prensiplerden taviz verilmesini önerdiğine inanılarak adını kullanmaktan bile kaçınılan hassas bir konuydu. Bu sorun aslında pazarlama prensiplerinin yanlış anlaşılmasından kaynaklanmaktaydı. Sanat organizasyonlarının faaliyet gösterdikleri değişen çevre şartları, gün geçtikçe daha fazla işletmeninin pazarlama prensiplerini kullanarak güvenilir ve pratik kararlar vermenin yanında yaratıcılık ve inovasyon için daha fazla olanak elde ettiklerini fark etmelerini sağlamıştır (Dickman 1997: 4). Bugün sanat pazarlaması, ürünün üretilmesinden önce pazarın ihtiyacının belirlenmesi ile başlayan geleneksel pazarlamadan farkııdır. Ürün odaklı yapısı gereği sanatçının sanatsal üretim surecini koruyarak bu surecin ürünü olan sanat eserinin üretilmesinden sonrası aşamaları içermektedir. Sanat eserini takdir etmesi olası müşteriler bulmak ve onlarla değer yaratan uzun vadeli ilişkiler kurmak sanat pazarlamasının temel amacını oluşturmaktadır. Bir diğer önemli amacı ise sanata ilgisiz insanları teşvik ederek onları sanat tüketicileri haline getirmektir.

Pazarlama stratejilerinin ve araçlarının kültürel organizasyonlara katkısı bugün genel olarak kabul edilmektedir. Bu özellikle, müşterilerinin ihtiyaç ve isteklerini tatmin ederek onları açık bir şekilde memnun etme çabalarıyla ürün yaratma sürecinde pazarlama prensiplerini benimseyen popüler sanat yöneticileri için doğrudur. Bununla birlikte misyon temelli sanatsal kurumlara son derece inanan en elitist ve tutucu sanat uzmanları bile pazarlamanın potansiyel faydalarını inkar edememektedirler. Özellikle kâr amacı gütmeyen kültürel organizasyonlar genellikle yüksek kalite sanat ürünlerini sunarak kültürel ve eğitimle ilgili misyonlarını gerçekleştirirken, pazarlamacılar tarafından tasarlanan iletişim ve tutundurma araçlarından da faydalanmaktadırlar (Addis ve Holbrook 2010: 141142).

Günümüzde sanat alanı geçmişten çok daha dinamik bir yapıdadır. Sponsorluk, yardımlar ve devlet desteği azalırken bu destekler için rekabet eden sanat organizasyonlarının sayısı ise artmaktadır. Colbert'e (2009: 1) göre sanat sektörü talebi aşan arzı ile doyuma ulaşmış ancak henüz olgunluk 
evresine girmemiştir. Markalarını konumlandırmak, müşterilerine sundukları hizmetlerin kalitesini artırmak ve daha bilgili müşteriler tarafından talep edilen bilgi teknolojilerini sağlamak sanat işletmelerinin başarması gereken pazarlama etkinlikleri haline gelmiştir. Dolayısıyla sanat işletmelerinden günümüzde beklenen, sanatsal bütünlükten taviz vermeden rekabet edebilmek için pazarlama stratejilerini işletmelerine uyarlamalarıdır (Colbert 2009: 1). Sanat işletmeleri bu zorlukları aşmak ve zorlu şartlarda sadece hayatta kalmak için değil aynı zamanda büyümek, gelişmek ve sadık destekçiler ile uzun süreli bir ilişki kurmak için bir pazarlama yaklaşımı geliştirirler (Dickman 1997: 5).

Günümüzde sanat pazarlamacıları heyecan verici ve oldukça zorlu zamanlar yaşamaktadırlar. Dünya değişmekte bununla birlikte insanların ürün ve deneyim satın alma şekilleri de değişmektedir. Eğer organizasyonlar hayatta kalmak istiyorlarsa, bu ürünleri ve deneyimleri destekleyen iş ve iletişim modellerini de değiştirmek zorundadır (Baxter 2010: 124).

Teknolojide gerçekleşen hızlı ilerlemelerle birlikte sanat işletmeleri evde, sokakta, neredeyse her an kullanılabilir hale gelen dijital, taşınabilir kültür ortamları ile yarışmak zorunda kalmıştır. Bu ortamlar insanlara, uygun yer ve zamanda çekici ve kullanışı kültürel aktiviteler sunmaktadır. Bugünkü sanat izleyicileri geçmişte kendileri için tiyatro ve sinema yapılan izleyicilerden çok farklıdırlar. Sunulan pasif ve biçimsel modelden daha aktif, kişiselleşmiş bir sanat tüketim deneyimi beklemektedirler. Kültürel tercihlerin, dağıtım kanallarının, tüketim biçimlerinin yaygınlaşması sebebiyle yadsınamaz şekilde insanların kültürle olan ilişkisi değişmiştir. İnsanlar önceden hazırlanmış "diyet" sanat ürününü tüketmek yerine, kendi kültürel menülerini aktif bir şekilde kişisel kimlik yapıları ve yaşam tarzları ile uyumlaştırarak hazırlamaktadırlar. Kültürel üretici ile tüketici arasındaki silikleşen engeller, güç dengesinde bir kayma yaratmaktadır. Sanat organizasyonları yetkilendirilmiş, kültürel olarak açılım yapmış, ayartıcı bir şekilde kendini gerçekleştiren bu yeni tüketici dalgası karşısında hızla yok olan bir otorite deneyimlemektedirler. İnsanlar kendilerine neyi görmeleri ve ne yapmaları veya nereye gitmeleri gerektiğinin söylenmesinden hoşlanmamaktadırlar. Artık kendileri için istedikleri şeyleri arama motorları ve kendiliğinden "viral" iletişimler aracılığıyla bulmaktadırlar (Baxter 2010: 124).

Tüm bu değişim ve gelişimler sanat pazarlamasının, günümüzde önemli bir kavram haline geldiğini göstermektedir. Geçmişte çeşitli endişelerle uzak durulan pazarlama bugün kâr amacı gütmeyen sanat işletmeleri yanında ticari sanat işletmelerinin de tüm diğer işletmeler gibi yönetim süreçlerine dâhil ettiği bir araçıır. Sanatın, sanatçıların, sanata aracılık eden kurumların varlıklarını sürdürülebilmeleri için bu ikilinin bir arada çalışarak, birbirini anlayarak, saygı göstererek hareket etmesi gerekmektedir. Sonuç olarak, etik değerlerden ödün vermeden, doğru uygulanan sanat pazarlaması sanatçıların ve sanatsal ürünlerin daha çok insanla buluşmasını kolaylaştırarak toplumda estetiğin ve yaratııılığın gelişmesini de sağlayabilecektir. 


\section{Kaynakça}

AÇIKGÖZ Aslı (2011), "Güzel Sanatların Meslek Rehberi", Milliyet Sanat, 39 (627), ss. 72-73.

ADDIS Michela ve HOLBROOK Morris B. (2010), Dreaming of Artistic Excellence, Popularity, or Both? Marketing the Arts: A Fresh Approach (Der: D. O'Reilly ve F. Kerrigan) New York, Routledge, ss. 141-152.

ATikOĞLU Ayça (2010), "İstanbul Yaratıcı Şehirler Merkezine Aday Oldu” Milliyet Sanat, 38 (621), ss. 30-31.

BAXTER Lisa (2010), From Luxury to Necessity: The Changing Role of Qualitative Research in the Arts, Marketing the Arts: A Fresh Approach (Der: D. O'Reilly ve F. Kerrigan), New York, Routledge, ss.121-140.

BECKER Howard S. (1978), "Arts and Crafts", American Journal of Sociology, 83 (4), pp. 862-889.

BENDIXEN Peter (2010), Managing Art: An Introduction into Principles and Conceptions, Berlin, LIT.

BERNSTEIN Joanne Scheff (2007), Arts Marketing Insights: The Dynamics Of Building And Retaining Performing Arts Audiences. (1. baskı), San Francisco, J. Wiley.

BLACKALL Simon ve MEEK Jan (der.) (1992), Marketing the Arts, Paris, ICOM.

BOORSMA Miranda (2006), "A Strategic Logic for Arts Marketing Integrating Customer Value And Artistic Objectives" International Journal of Cultural Policy, 12 (1), pp. 73-92.

BOORSMA Miranda ve CHIARAVALLOTI Francesco (2009), "Arts marketing and performance management: closing the gap between mission and indicators", Proceedings of the 5th Conference on Performance Measurement and Management Control, 23-25 September 2009, Nice.

BOTTI Simona (1999), "What Role for Marketing in the Arts? An Analysis of Art Consumption and Artistic Value", 3th International Research Seminar on Marketing Communications and Consumer Behavior, Aix-en-Provence (France), pp. 28-47.

BYRNES William (2009), Management and the Arts, U.S.A., Elsevier.

CHONG Derrick (2010), Arts Management, New York, Routledge.

COLBERT François (2003), "Entrepreneurship and Leadership in Marketing the Arts" International Journal of Arts Management, 6 (1), pp. 30-39.

COLBERT François (2009). Beyond Branding: Contemporary Marketing Challenges For Arts Organizations, Deakin Print Services, Logistics Division, Deakin University. 
DEMIRDÖVEN Jale Bozoğlu ve ÖDEKAN Ayla (2008), "Müzayedelerin Sanat Piyasalarındaki Rolü ve Türkiye'deki Yansımaları", iTü Dergisi/b, 5 (1), ss. 55-66.

DENNIS Noel ve MACAULAY Michael (2010), Musinga from Miles: What Miles Davis Can Tell Us about Music and Marketing, Marketing The Arts: A Fresh Approach (Der: D. O’Reilly ve F. Kerrigan), New York, Routledge, ss. 205-213.

DICKMAN Sharron (1997), Arts Marketing: The Pocket Guide. Australia Center for the Arts \& Centre for Professional Development Publication.

DIGGLE, Keith (1994), Arts Marketing, London, Rhinegold Pub.

EHRMANN Thierry (2011), "Art Market Trends 2010".

ERTÜRK, İsmail (2011), "1.3 Trilyon Dolardan Pay Almak için Yaratıcı Sanayici"

EVRARD Yves ve COLBERT François (2000), "Arts Management: A New Discipline Entering the Millennium?", International Journal of Arts Management, 2 (2), pp. 4-13.

FILLIS lan (2002), "Creative Marketing And The Art Organisation: What Can The Artist Offer?", International Journal of Nonprofit and Voluntary Sector Marketing, 7 (2), pp. 131-145.

FILLIS lan (2006), "Art For Art's Sake Or Art For Business Sake: An Exploration Of Artistic Product Orientation", The Marketing Review, 6 (1), pp. 29-40.

FILLIS Ian (2010), The Tension Between Artistic and Market Orientation in Visual Art. Marketing The Arts: A Fresh Approach (Der: D. O'Reilly ve F. Kerrigan). New York, Routledge, pp. 31-39.

GAINER Brenda (1989), "The Business of High Culture: Marketing the Performing Arts" The Service Industries Journal, 9 (4), pp. 143-161.

GOODMAN Calvin J. (1991), Art Marketing Handbook: Marketing Art in the Nineties, (Gözden geçirilmiş ve genişletilmiş 6. baskı), Los Angeles, Calif., Gee Tee Bee.

GUILLET DE MONTHOUX Pierre (2004), The Art Firm: Aesthetic Management and Metaphysical Marketing, Stanford, Calif., Stanford Business Books.

HAYES Debi ve ROODHOUSE Simon (2010), From Missionary to Market Maker: Reconceptualizing Arts Marketing in Practice. Marketing the Arts: A Fresh Approach, Der: D. O'Reilly ve F. Kerrigan, New York, Routledge, pp. 40-53.

HILL Lizz, O'SULLIVAN Catherine ve O'SULLIVAN Terry (2003), Creative Arts Marketing (2. baskı), Amsterdam, Butterworth-Heinemann.

HIRSCHMAN Elizabeth C. (1983), "Aesthetics, Ideologies and the Limits of the Marketing Concept" Journal of Marketing, 47 (3), pp. 45-55. 
HOROWITZ Noah (2011), Art of the Deal: Contemporary Art in a Global Financial Market, London, Princeton University Press. http://imgpublic.artprice.com/pdf/ trends2010_en.pdf, [20.01.2012]

http://www.milliyet.com.tr/1-3-trilyon-dolardan-pay-almak-icin-yaratici-sanayici/ ekonomi/ekonomidetay/09.12.2011/1473147/default.htm, [18.11.2015]

İbrahim Demirel ile 18 Mart 2011 tarihinde yapılan görüşme, Ankara.

KERRIGAN Finola, FRASER Peter ve ÖZBILGIN Mustafa (2004), Arts Marketing, Amsterdam, Elsevier Butterworth-Heinemann.

KERRIGAN Finola, O'REILLY Daragh ve VOM LEHN Dirk (2009), "Producing and Consuming Arts: A Marketing Perspective", Consumption Markets \& Culture, 12 (3), pp. 203- 207.

KOLB Bonita M. (2005), Marketing for Cultural Organisations: New Strategies For Attracting Audiences To Classical Music, Dance, Museums, Theatre \& Opera (2. baskı), London, Thomson Learning.

KOTLER Philip ve LEVY Sidney J. (1969), "Broadening the Concept of Marketing", The Journal of Marketing, 33 (1), pp. 10-15.

KOTLER Philip ve SCHEFF Joanne (1997), Standing Room Only: Strategies for Marketing the Performing Arts. Harvard Business School Press, Boston, MA.

KUBACKI Krzysztof ve CROFT Robin (2004), "Mass Marketing, Music and Morality", Journal of Marketing Management 20 (5-6), pp. 577-590.

KUBACKI Krzysztof ve CROFT Robin (2006), "Artists' Attitudes to Marketing: A Cross-Cultural Perspective", International Journal of Nonprofit and Voluntary Sector Marketing, 11 (4), pp. 335-345.

KUBACKI Krzysztof ve O'REILLY Daragh (2009), Arts Marketing. Contemporary Issues in Marketing and Consumer Behaviour (Der: E. Parsons ve P. Maclaran). Oxford, Elsevier, pp. 55-72.

LEE Hye-Kyung (2005), "When Arts Met Marketing Arts Marketing Theory Embedded In Romanticism", International Journal of Cultural Policy, 11 (3), pp. 289-305.

MEYER Jörn-Axel ve EVEN Ralf (1998), "Marketing and the Fine Arts - Inventory of a Controversial Relationship", Journal of Cultural Economics, 22 (4), pp. 271283.

MICOCCI Tony (2008), Booking Performance Tours: Marketing and Acquiring Live Arts And Entertainment, New York, Alworth Pres.

MOKWA Michael P., DAWSON William M. ve PRIEVE E. Arthur (eds.) (1980), Marketing the Arts, New York, Praeger.

O'REILLY Daragh (2005), "Cultural Brands/Branding Cultures", Journal of Marketing Management, 21 (5-6), pp. 573-588. 
O'REILLY Daragh ve KERRIGAN Finola (Editors)(2010), Marketing the Arts: A Fresh Approach, New York, Routledge.

ÖNSAL Başak (2006), Emergence of Art Galleries in Ankara. A Case Study of Three Pionerring Galleries in the 1950s, Yayınlanmamış Yüksek Lisans Tezi, Ortadoğu Teknik Üniversitesi, Ankara.

PLATTNER Stuart (1998), "A Most Ingenious Paradox: The Market for Contemporary Fine Art", American Anthropologist, New Series, 100( 2), pp. 482493.

RENTSCHLER Ruth (1998), "Museum and Performing Arts Marketing: A Climate of Change" Journal of Arts Management, Law, and Society, 28 (1), pp. 83-96.

RENTSCHLER Ruth (2002), "Museum and Performing Arts Marketing: The Age of Discovery", The Journal of Arts Management, Law, and Society, 32 (1), pp. 7-14.

RENTSCHLER Ruth (2007), "Guest editorial Arts marketing", International Journal of Nonprofit and Voluntary Sector Marketing, 12 (2), pp. 91-93.

RENTSCHLER Ruth ve SHILBURY David (2008), "Academic Assessment of Arts Management Journals: A Multidimensional Rating Survey", International Journal of Arts Management, 10 (3), pp. 60-71.

ROBERTSON lain (2005), The International Art Market. Understanding International Art Markets and Management, Der: I. Robertson, New York, Routledge, pp. 13-36.

ROBERTSON lain (Ed.) (2005), Understanding International Art Markets and Management, New York, Routledge.

RYAN Annmarie, FENTON Matt ve SANGIORGI Daniela (2010), A Night at the Theatre: Moving Arts Marketing from the Office to the Kitchen and beyond. Marketing the Arts: A Fresh Approach, Der: D. O'Reilly ve F. Kerrigan, New York, Routledge, pp. 214-230.

SCHEFF Joanne ve KOTLER Philip (1996), "Crisis in the Arts: The Marketing Response", California Management Review, 39 (1), pp. 28-52.

STALLABRASS Julian (2010), Sanat A.Ş. Çağdaş Sanat ve Bienaller, (2.baskı), Çev. Esin Soğancılar, İstanbul, İletişim Yayınları.

THOMPSON Don (2011), Sanat Mezat, Çev. Renan Akman, İstanbul, İletişim Yayınları.

VELTHUIS Olav (2005), Talking Prices: Symbolic Meanings Of Prices On The Market For Contemporary Art, U.S.A, Princeton University Press.

WANG Xuan (2009), Gallery's Role in Contemporary Chinese Art Market, Yayınlanmamış Yüksek Lisans Tezi, The Ohio State University, Ohio. 